\title{
Measurement of the force necessary for removal of bacterial cells from a quartz plate
}

\author{
HISAO MORISAKI \\ Institute of Genetic Ecology, Tohoku University, 2-1-1 Katahira, Sendai 980, Japan
}

(Received 6 February 1991; revised 6 May 1991; accepted 26 July 1991)

\begin{abstract}
The force necessary to remove the cells of a bacterium, an isolate (Bacillus sp.) from grassland soil, from a quartz plate was investigated in phosphate buffer solution by using a well-defined liquid flow caused by electroosmosis. The cells were not removed at a specific strength of removal force but removed over a wide range of force, about $10^{-14}-10^{-12} \mathrm{~N}$ per cell. An exponential relation was observed between the removal force and the number of removed cells in media of $\mathrm{pH} \mathrm{7.0,8.0}$ and 9.0; more cells were removed by a smaller force. Experiments in media of different $\mathrm{pH}$ values in the range 3.0 to 9.0 showed that greater force was necessary to remove the cells in media of lower $\mathrm{pH}$. The smaller electrostatic repulsion between the bacterial cells and the quartz plate at lower $\mathrm{pH}$ values was considered to result in the greater force needed for removal. The relation between the strength of the removal force and the strength of the adhesion force of the bacterial cells was considered. The findings showed that the cell adhesion was reversible and that the adhesion site was located near the end of the cell.
\end{abstract}

\section{Introduction}

In the natural environment many micro-organisms strongly prefer the surface regions of soils, plant fibres, roots, etc. The attachment of micro-organisms at a solid surface enables them to benefit from the enriched nutrient status at the surface. In flowing systems, such as the oral cavity, rocks and plant surfaces in streams and ship surfaces, attachment to surfaces ensures that the micro-organisms are not eliminated from the particular ecosystem. Understanding of the mechanism of microbial adhesion should therefore be helpful in revealing the behaviour of micro-organisms in natural ecosystems. Physicochemical analysis of the interaction between micro-organisms and substrate surfaces under welldefined experimental conditions is a useful way to investigate the adhesion mechanism. Application of the DLVO theory of colloid stability or use of thermodynamic parameters, i.e. interfacial free energy, are the two most common approaches currently employed (Marshall, 1976; Rutter \& Vincent, 1980; Tadros, 1980; Absolom et al., 1983; Busscher et al., 1984; Van Loosdrecht et al., 1987; Pratt-Terpstra et al., 1987). For further progress in formulating a physicochemical theory of bacterial adhesion, an understanding of the interaction strength between bacterial cells and substrate surfaces seems to be essential. However, the available

Abbreviation: EPM, electrophoretic mobility. data on the interaction strength are rather limited due to difficulties in measuring the strength quantitatively.

The purpose of this study was to test an experimental system for measuring the interaction force by observing removal of bacterial cells with a microscope under welldefined hydrodynamic conditions. For this purpose, an electrokinetic method, which has been used for the study of the removal force of non-living colloidal particles (Gotoh et al., 1983, 1984; Tagawa \& Gotoh, 1986), was adopted to produce smooth liquid-flow resulting in cell removal by its viscous drag. A representative grassland soil isolate, Bacillus sp., was used for the measurement of the removal force from a quartz plate to which the cells were attached. The effect of $\mathrm{pH}$ on the removal force was also investigated. The relation between the removal force and the adhesion force was considered.

\section{Methods}

Organism and culture conditions. A strain of Bacillus sp. (GI-103) isolated from grassland soil was used. The bacterium, kindly provided by Y. Kasahara (Tohoku University), had a long rod shape (about $7.0 \mu \mathrm{m} \times 1.2 \mu \mathrm{m})$ and represented a group which showed the highest growth rate compared with other groups of isolates (Y. Kasahara \& T. Hattori, unpublished results).

Strain GI-103 was cultured in $200 \mathrm{ml}$ diluted nutrient broth (DNB), the same medium as used to isolate bacteria from grassland soil, containing $0.1 \mathrm{~g}$ meat extract, $0.1 \mathrm{~g}$ peptone and $0.05 \mathrm{~g} \mathrm{NaCl}$ per litre of tap water (pH 7). The culture was shaken aerobically (150 r.p.m.) at 


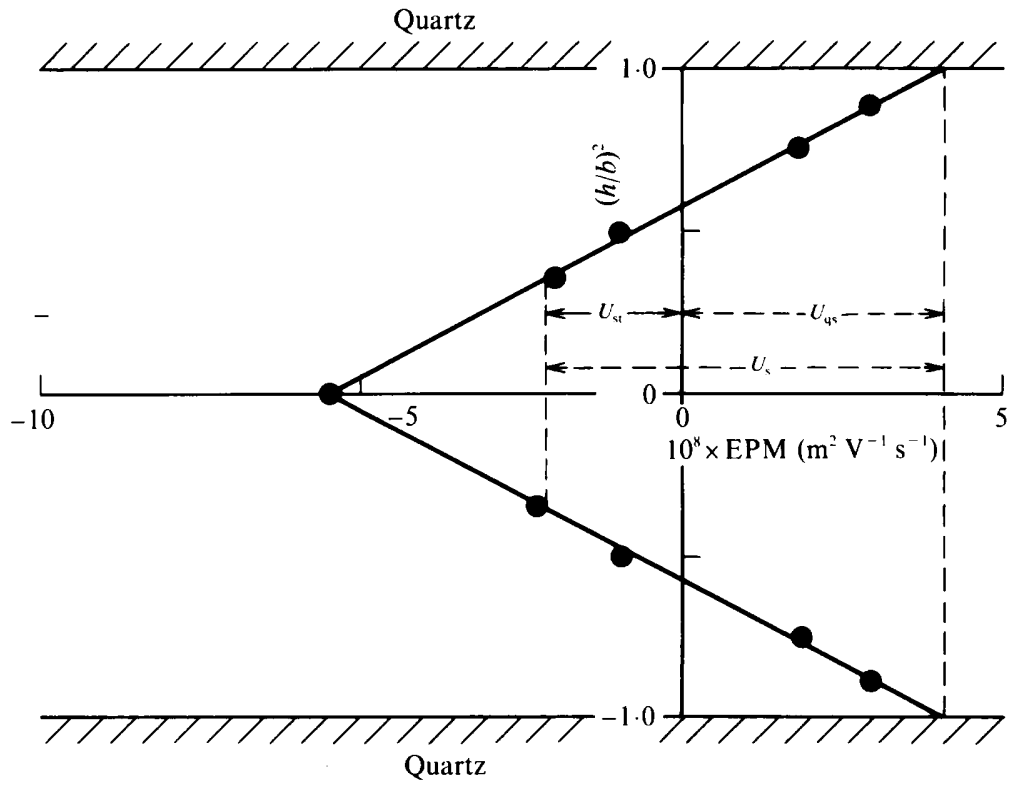

Fig. 1. Van Gils' plot of amphoteric polystyrene particles in $10 \mathrm{~mm}$-phosphate buffer $(\mathrm{pH} 7.0)$ at $25^{\circ} \mathrm{C} ; b$ is the half thickness of the cell and $h$ the level from the centre. Mean of two measurements; standard error was smaller than $0 \cdot 1$ $\left(\times 10^{-8} \mathrm{~m}^{2} \mathrm{~V}^{-1} \mathrm{~s}^{-1}\right)$. $27^{\circ} \mathrm{C}$ and harvested after $7.0 \mathrm{~h}$, when the cells were in the exponential growth phase. The cell suspension was centrifuged at $5600 \mathrm{~g}$ for $5 \mathrm{~min}$ at $25^{\circ} \mathrm{C}$ and washed twice with $10 \mathrm{mM}$-phosphate-buffered saline (PBS) $\left(\mathrm{NaCl}, 0.526 \mathrm{~g} ; \mathrm{Na}_{2} \mathrm{HPO}_{4}, 0.142 \mathrm{~g}\right.$; distilled water, $1000 \mathrm{ml}$ ). The $\mathrm{pH}$ of the buffer was adjusted with $20 \mathrm{mM}-\mathrm{HCl}$ or $\mathrm{NaOH}$ to maintain a constant ionic strength. The bacterial cells were resuspended in the buffer to a concentration of $10^{7}$ cells $\mathrm{ml}^{-1}$, and this suspension was then placed in a quartz cell for the removal experiment.

Attachment and removal of bacterial cells. The inner surface of the upper plate of a rectangular quartz cell (Mitamura Rikagaku, Japan, $24 \mathrm{~mm} \times 75 \mathrm{~mm}$, depth $1.1 \mathrm{~mm}$ ) for electrophoresis was used as the substrate surface for adhesion. The quartz cell was filled with a suspension of bacterial cells (about $10^{7}$ cells $\mathrm{ml}^{-1}$ ) and turned over for 30 min to allow the bacterial cells to come into contact with the inner wall of the upper plate of the quartz cell. The quartz cell was then returned to its normal position and placed on the stage of the microscope. The quartz cell was left for $5 \mathrm{~min}$ before removal experiments to allow the unattached bacterial cells to move away from the quartz wall. To remove the attached cells, an electric field was applied parallel to the wall by using platinized platinum electrodes, generating an electroosmotic flow of the buffer solution along the wall. The electric field was increased stepwise after a constant strength of electric field had been maintained for $20 \mathrm{~s}$ to $1 \mathrm{~min}$ : $1 \mathrm{~min}$ for field strengths of 0.51 to $8.4 \mathrm{~V} \mathrm{~cm}^{-1}, 30 \mathrm{~s}$ for 9.6 to $13.1 \mathrm{~V} \mathrm{~cm}^{-1}$ and $20 \mathrm{~s}$ for $15 \cdot 1$ to $27 \cdot 1 \mathrm{~V} \mathrm{~cm}^{-1}$; the shorter time was used for the higher field strength to minimize the turbulent effect of gas and heat produced by electrolysis of water.

Removal of the bacterial cells was observed and recorded under a phase-contrast microscope (Olympus BH-2, Japan) connected to a video recorder (Victor BR-9000, Japan) with a video camera (Victor $\mathrm{GX}-\mathrm{N} 4 \mathrm{CH}$, Japan). The video images were analysed as follows. Each cell attached to the quartz wall was marked on the monitor screen at the initial position before application of the electric field. The number of bacterial cells $(N)$ remaining at the initial position on the wall after this application was counted by comparing the video image with the marked positions. The removal ratio was expressed as $\left(N_{0}-N\right) / N_{0}$, where $N_{0}$ is the number of bacterial cells attached before the application of the electric field; the mean of $N_{0}$ in the area observed $(340 \mu \mathrm{m} \times 450 \mu \mathrm{m})$ was 91 cells (standard error $=67$ cells, $n=16)$.
Measurements of electrophoretic mobility and electroosmotic liquid flow. The electrophoretic mobility (EPM) of the bacterial cells was measured by micro-electrophoresis in buffer varying in $\mathrm{pH}$ from $3 \cdot 0$ to $9 \cdot 0$. The EPM of bacterial cells was determined at the upper stationary level of the quartz cell mounted on a microscope (Olympus BH-2) fitted with a dark-field condenser, a rotating prism system (Rank Brothers, UK) and a DC power supply. The moving speed of the prism $\left(V_{\mathrm{p}}, \mu \mathrm{m} \mathrm{s}^{-1}\right)$ and the strength of the electric field $\left(E, \mathrm{~V} \mathrm{~cm}^{-1}\right)$ were adjusted to make the bacterial cells appear to be stationary to determine their EPM $\left(V_{\mathrm{p}} \times \mathrm{E}^{-1}\right)$.

The electroosmotic liquid velocity at the quartz surface, $U_{\mathrm{s}}$, was calculated by measuring the velocity of polystyrene particles at the stationary level $\left(U_{\mathrm{st}}\right)$ and the quartz surface $\left(U_{\mathrm{qs}}\right)$; both velocities, $U_{\mathrm{st}}$ and $U_{\mathrm{qs}}$, were determined from a van Gils' plot (Fig. 1).

All experiments in this study were carried out in a room maintained at constant temperature $\left(25^{\circ} \mathrm{C}\right)$.

\section{Results}

\section{Characteristics of strain GI-103}

Cells of strain GI-103 in the exponential phase, cultured aerobically for $7.0 \mathrm{~h}$, were used for the removal experiments. The cells were of long rod shape, Gram-staining positive and motile with peritrichous flagella. The length of the cells varied from $3.2 \mu \mathrm{m}$ to $10.7 \mu \mathrm{m}$ $(6.95 \pm 1.73 \mu \mathrm{m}, n=55$; mean and standard error of 55 cells), while most cells had an almost constant width of $1.0-1.5 \mu \mathrm{m}$. There was little difference in width at three positions along the cell $(1.25 \pm 0.13,1.23 \pm 0.18$ and $1.24 \pm 0.12 \mu \mathrm{m}$ at positions 25,50 and $75 \%$ of the cell length, respectively, $n=55$; Fig. $2 a$ ). The cells in the stationary phase, after culturing for $24 \mathrm{~h}$, were nonmotile and had endospores (Fig. $2 b$ ). Spores were ovoid in shape (length $1 \cdot 4 \pm 0 \cdot 1$, width $0.8 \pm 0 \cdot 1 \mu \mathrm{m}, n=19$ ) 

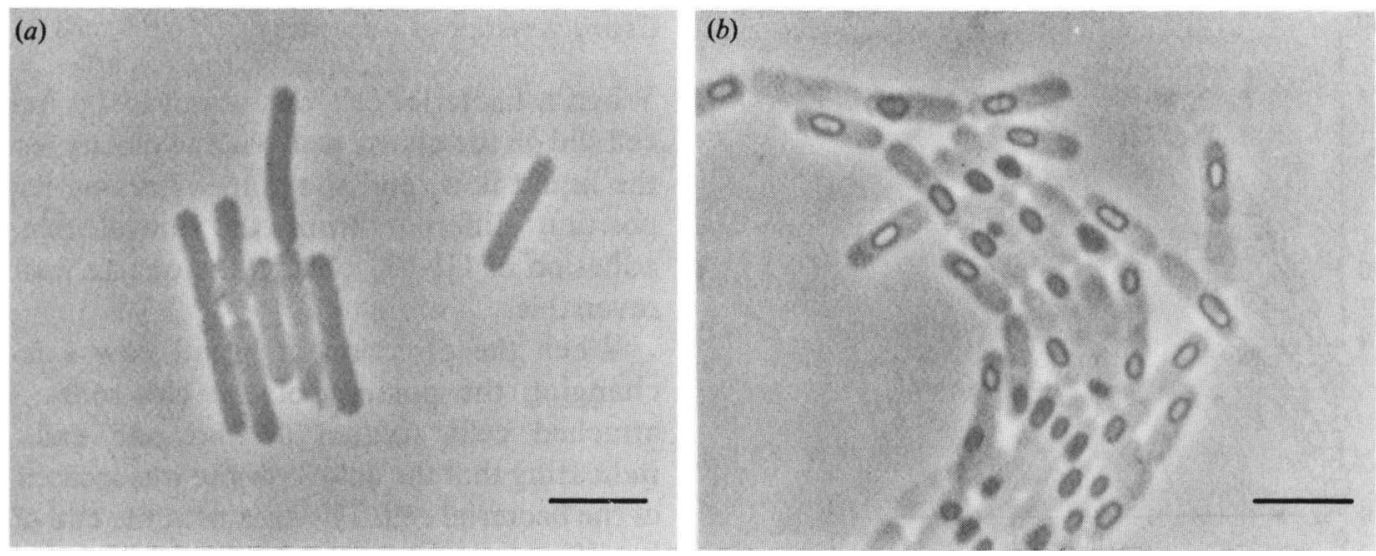

Fig. 2. Cells of strain GI-103. (a) Cells cultured for $7 \mathrm{~h}$; (b) cells cultured for $24 \mathrm{~h}$. Bars, $5 \mu \mathrm{m}$.

and positioned with the centre of the spore at a distance of $(0.31 \pm 0.06) \times$ cell-length $(n=19)$ from the end of the cell. These characteristics indicate that this bacterium is a strain of the genus Bacillus.

\section{Effect of liquid velocity on cell removal}

The changes in the removal efficiency of bacterial cells $\Delta N / N_{0}$, where $\Delta N$ is the number of bacterial cells removed at a certain liquid velocity and $N_{0}$ is the number initially attached to the quartz surface, as a function of the liquid velocity are shown in Fig. 3 for medium of $\mathrm{pH} 7 \cdot 0$. The removal efficiency did not show any specific peak related to changes in the liquid velocity, but decreased exponentially with increasing liquid velocity. This result indicates that there is no specific strength for the interaction between the attached bacterial cells and the quartz wall.

The removal ratio, $\left(N_{0}-N\right) / N_{0}$, an accumulation of the removal efficiency described above, is plotted against the liquid velocity in Fig. 4. This plot shows that the number of bacterial cells removed from the quartz wall increased exponentially as the liquid velocity increased.

\section{Effect of $p H$ on the removal efficiency and the removal ratio}

Cell removal was examined in media varying in $\mathrm{pH}$ from 3.0 to $9 \cdot 0$. The removal efficiency decreased exponentially against the liquid velocity in media of $\mathrm{pH} \mathrm{9.0,8.0} \mathrm{and,}$ as previously shown, $7 \cdot 0$, while the exponential relation became unclear in the media of lower $\mathrm{pH}$.

The removal ratio was plotted against the liquid velocity for media varying in $\mathrm{pH}$ (Fig. 5). At all pHs tested similar relations to that obtained at $\mathrm{pH} 7.0$ (Fig. 4)

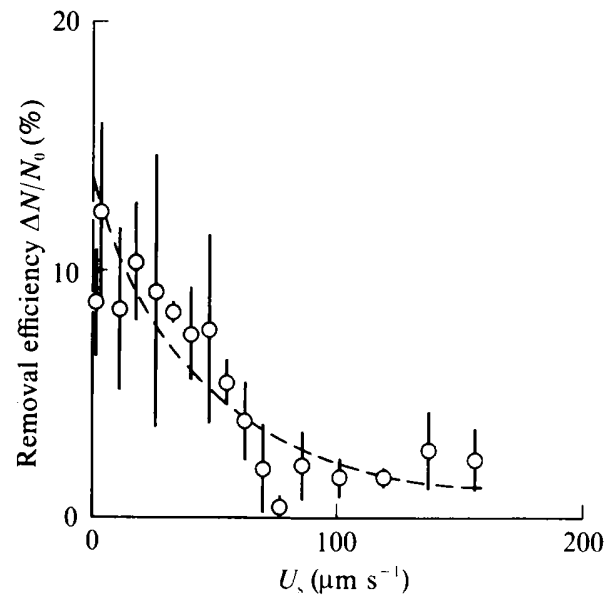

Fig. 3. Removal efficiency of GI-103 cells as a function of liquid velocity at the surface. $O$, Mean and standard error of three experiments in $10 \mathrm{mM}$-phosphate buffer at $\mathrm{pH} 7.0$ and $25^{\circ} \mathrm{C}$. Mean of $N_{0}$ was 140 cells $(\mathrm{SE}=50, n=3)$.

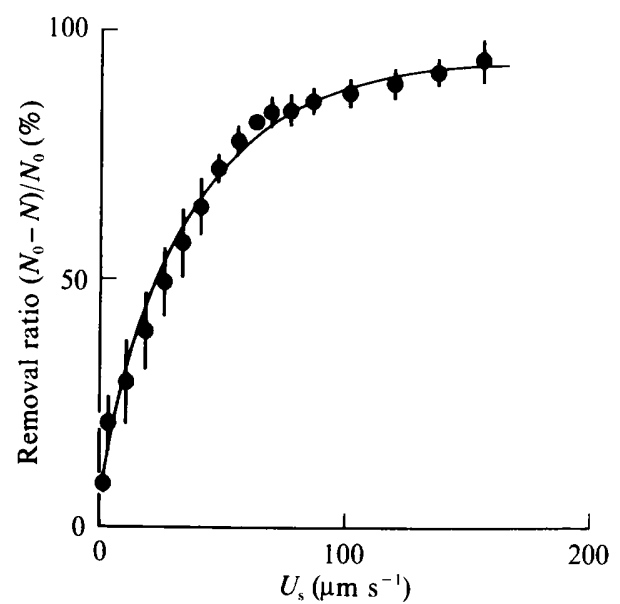

Fig. 4. Removal ratio of GI-103 cells as a function of liquid velocity at the surface. Mean and standard error of three experiments in 10 mM-phosphate buffer $\left(\mathrm{pH} \mathrm{7.0)}\right.$ at $25^{\circ} \mathrm{C}$. Mean of $N_{0}$ was 140 cells $(\mathrm{SE}=50, n=3)$. 


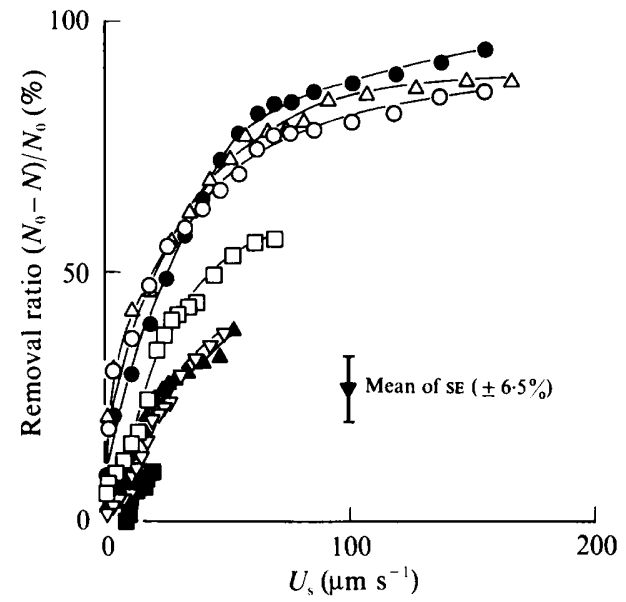

Fig. 5. Effect of $\mathrm{pH}$ on the removal of GI-103 cells. Experiments were done twice for $\mathrm{pH} 4(\nabla), 5(\Delta), 6(\square), 8(O)$ and $9(\triangle)$, and three times for $\mathrm{pH} 3(\square)$ and $7(\mathbf{\square})$. ( $)$, Mean of standard error was $6.5 \%$ $(n=108)$. Mean of $N_{0}$ was 91 cells $(\mathrm{SE}=67, n=16)$.

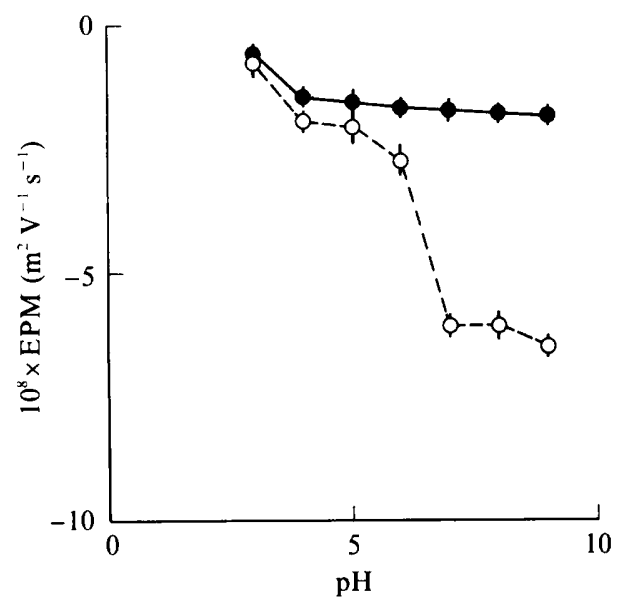

Fig. 6. Electrophoretic mobility (EPM) of GI-103 cells (O) and the quartz wall $(\mathrm{O})$ as a function of $\mathrm{pH}$ at $25^{\circ} \mathrm{C}$. The results are means and standard errors of two experiments.

were observed. However, more cells remained on the quartz wall at lower $\mathrm{pH}$ values. This indicates that cell removal became more difficult and needed greater force in medium of lower $\mathrm{pH}$.

\section{Electrostatic charges of bacterial cells and the quartz wall}

The electrophoretic mobility (EPM) of the bacterial cells and the quartz wall is shown in Fig. 6 as a function of pH. The EPM of the quartz wall was determined by reversing the sign of the electroosmotic liquid flow at the wall. Both the EPM of the bacterial cells and that of the quartz wall decreased at lower $\mathrm{pH}$ values, indicating less negative charges on these surfaces at lower $\mathrm{pH}$ values.
Characteristics of adhesion of GI-103 cells

When a bacterial cell was removed by liquid flow, the cell slid on the quartz wall with a velocity less than that of the liquid flow, and sometimes became reattached at a position different from the initial one. Thus, the adhesion of GI-103 cells to the quartz wall seems to be reversible.

When the direction of liquid flow was reversed by changing the polarity of the electrodes, most of the attached cells rotated around one end of the cell, indicating that the adhesion site was located near the end of the bacterial cell. The area near the end of the cell may be different in surface properties from other parts of the cell.

\section{Discussion}

When an electric field is applied, the bacterial cell attached to the quartz wall experiences two kinds of forces, a hydrodynamic drag force $\left(F_{\mathrm{hd}}\right)$ and an electrokinetic force $\left(F_{\text {ek }}\right)$ parallel to the quartz wall (see Fig. 10). $F_{\text {hd }}$ is given by the following equation (Goldman et al. 1967):

$$
F_{\text {hd }}=1.7 \times 6 \pi \eta a U_{\mathrm{s}}
$$

where $\eta$ is the viscosity of the liquid $\left(8.9 \times 10^{-4} \mathrm{~Pa}\right.$ s for $10 \mathrm{mM}$-PBS at $25^{\circ} \mathrm{C}$ ), $a$ is the radius of the bacterial cell (this value will be considered below), and $U_{\mathrm{s}}$ is the electroosmotic liquid velocity at the quartz surface. On the other hand, the electric field, which causes the electroosmotic liquid flow, works on the bacterial cells in the opposite direction. This force is equal to

$$
F_{\text {ek }}=6 \pi \eta a U_{\mathrm{e}}
$$

where $U_{\mathrm{e}}$ is the electrophoretic velocity of the bacterial cells at the stationary level.

Thus, the net force, $F_{\text {eff }}$, which effectively works on the bacterial cells causing them to move along the quartz wall, can be given by

$$
\begin{aligned}
F_{\text {eff }} & =1.7 \times 6 \pi \eta a U_{\mathrm{s}}-6 \pi \eta a U_{\mathrm{e}} \\
& =6 \pi \eta a\left(1.7 U_{\mathrm{s}}-U_{\mathrm{e}}\right)
\end{aligned}
$$

The removal ratio of the bacterial cells is plotted against

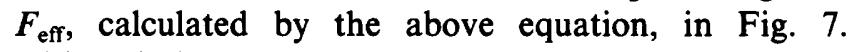
Although the cells were rod-shaped, they were treated as a spherical particle with a radius of $0.62 \mu \mathrm{m}$, half the width of the cell, because when the liquid velocity was increased, most of cells rotated around one end of the cell, following the long axis of the cell parallel to the direction of the liquid flow. 


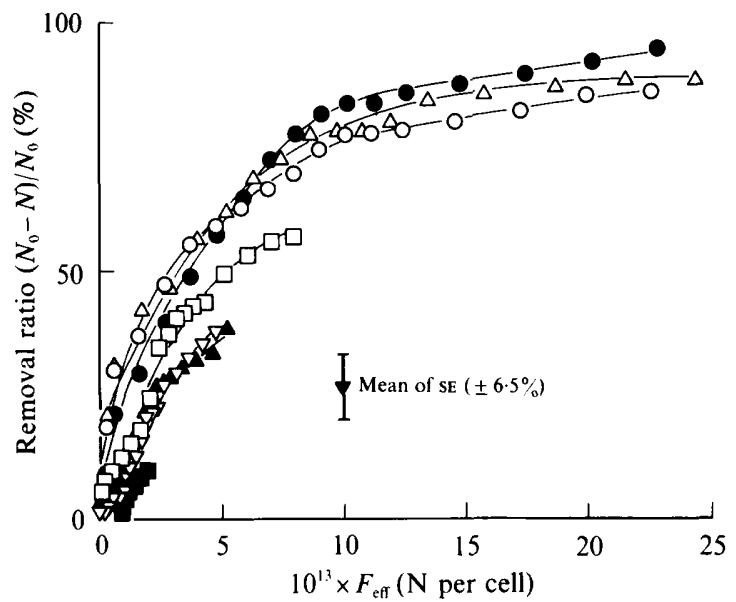

Fig. 7. Relation between removal force, $F_{\text {eff }}$, and removal ratio for GI103 cells. Experiments were done twice for $\mathrm{pH} 4(\nabla), 5(\Delta), 6(\square), 8$ $(O)$ and $9(\triangle)$, and three times for pH $3(\square)$ and $7(\bullet)$. ( $)$, Mean of standard error was $6.5 \%(n=108)$. Mean of $N_{0}$ was 91 cells $(\mathrm{SE}=67$, $n=16$ ).

If the interaction strength between the bacterial cells and the quartz wall had a specific value, most cells would be removed at a specific removal force. The results shown in Fig. 7 indicate that this is not the case. The removal ratio increased exponentially against $F_{\text {eff }}$ at $\mathrm{pH} 7 \cdot 0,8 \cdot 0$ and $9 \cdot 0$, indicating that there was no specific strength for the removal force, but rather that the force is distributed exponentially among the attached cells over a wide range. The exponential relation became unclear in the media of lower $\mathrm{pH}$ because of small values and large divergences in the removal ratio. The exponential distribution of the removal force may reflect inconstant surface properties among the cells, e.g. surface charge, surface composition or area of contact.

The relations shown in Fig. 7 were fitted to regression curves by the least-squares method. Although no specific value for the removal force could be found, the values of $F_{\text {eff }}$ necessary to remove $10,20,30,40$ and $50 \%$ of the initial cells could be calculated from the regression curves. These $F_{\text {eff }}$ values were plotted against electrostatic relative-repulsion between the bacterial cells and the quartz wall (Fig. 8): the repulsion at pH 7, (EPM of bacterial cell $) \times(E P M$ of quartz wall), was set as 1 for the calculation of the relative repulsion at other $\mathrm{pH}$ values. As shown in Fig. 8, when electrostatic repulsion is smaller, greater force is necessary to remove the bacterial cells from the quartz wall. The smaller repulsion will decrease the distance between the bacterial cell and the quartz wall, if the cell is attached at the secondary minimum as discussed based on the DLVO theory (Marshall, 1976; Rutter \& Vincent, 1980; Tadros, 1980). This may lead to a stronger interaction, such as

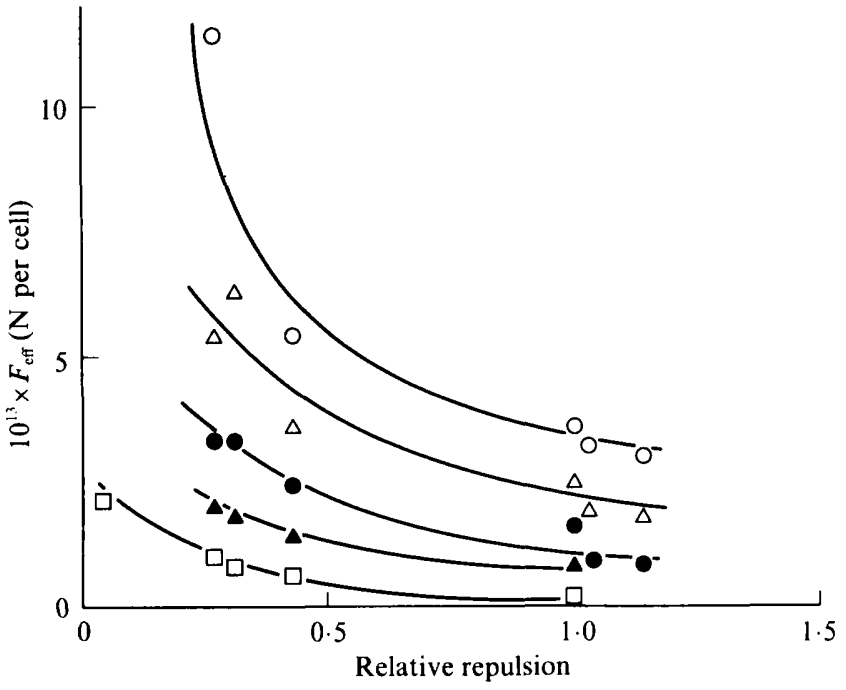

Fig. 8. Relation between electrostatic relative-repulsion and removal force for GI-103 cells: removal of $10 \%(\square), 20 \%(\Delta), 30 \%(O), 40 \%$ $\triangle)$ and $50 \%(O)$ of the initially attached cells. The relative repulsion was calculated from the EPM values of the bacterial cell and quartz wall by setting the repulsion between these two bodies at $\mathrm{pH} 7$ as 1 .

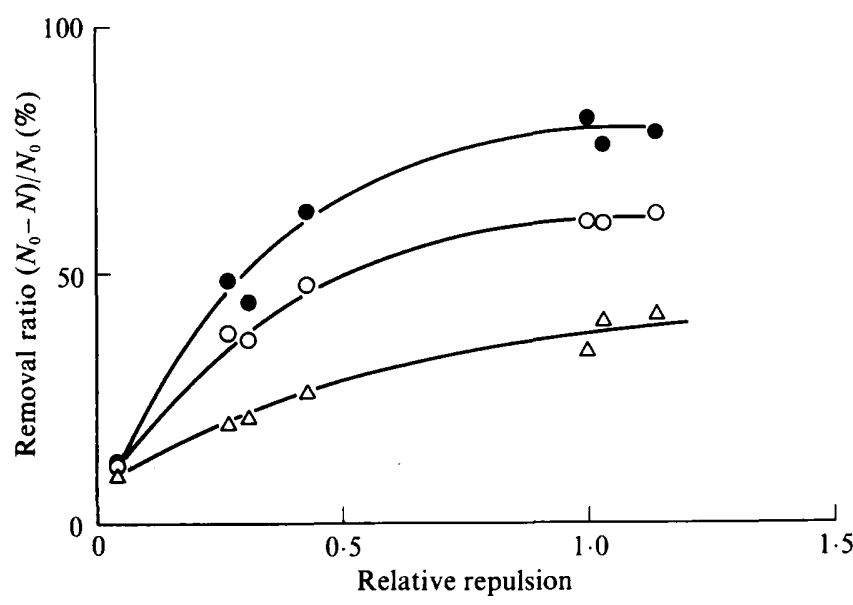

Fig. 9. Relation between electrostatic relative-repulsion and removal ratio at various strengths of removal force, $2.0(\triangle), 5.0(O)$ and $10.0 \times 10^{-13} \mathrm{~N}$ per cell $(\mathrm{O})$.

van der Waals forces, between these two bodies, resulting in the greater force necessary for cell removal.

In some studies, substrate surfaces for cell adhesion were rinsed with liquid to wash away unattached bacterial cells, and the cells that remained on the surfaces were counted as attached cells. This kind of procedure seems to correspond to removal of the cells at a certain flow rate of liquid, i.e. a constant removal force is exerted on the attached cells, if the rinsing procedure is carefully performed. In Fig. 9 the relation between the removal ratio under a removal force of 2.0, 5.0 and $10.0 \times 10^{-13}$ $\mathrm{N}$ per cell is plotted against electrostatic relativerepulsion between the bacterial cells and the quartz wall. 

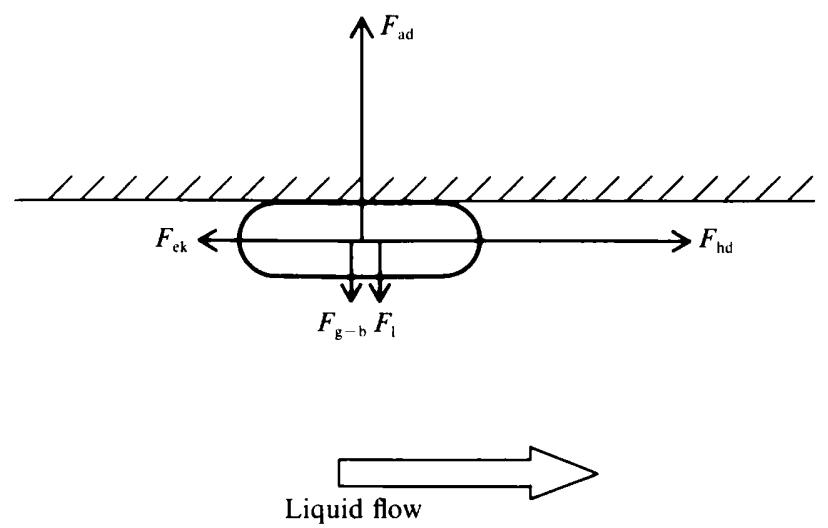

Fig. 10. Forces acting on a bacterial cell attached to the inner face of the upper quartz plate. $F_{\mathrm{hd}}$, hydrodynamic drag force; $F_{\mathrm{ek}}$, electrokinetic force; $F_{\mathrm{ad}}$, adhesion force; $F_{\mathrm{g}-\mathrm{b}}$, the difference between gravitation and buoyancy force; $F_{1}$, lift force due to change in stream line of liquid flow.

As the electrostatic repulsion between these two bodies increases and/or greater removal force is exerted, fewer cells can remain on the quartz wall. This tendency is in agreement with the results obtained in other studies (Kaneko \& Colwell, 1975; Van Loosdrecht et al., 1987; Bashan \& Levanony, 1988; Hermesse et al., 1988). These results might be due to the exponential distribution of the force for cell removal as revealed in the present study.

In Fig. 10 all forces expected to act on a bacterial cell on the quartz wall are shown. Obviously, the removal force, $F_{\text {eff }}=F_{\text {hd }}-F_{\text {ek }}$, is perpendicular to the adhesion force. This means that the removal force obtained in this study does not directly correspond to the adhesion force. However, if some relation between these two forces can be found, it may be possible to estimate the adhesion force from the removal force indirectly. It has been reported that the ratio (removal force)/(adhesion force) could be assumed to be about 140 for removal of $50 \%$ of nylon particles attached to a quartz wall (Gotoh et al., 1984); the adhesion force was calculated by the heterocoagulation theory and compared with the removal force. At the present time it is impossible to calculate this ratio for a bacterial cell on a quartz wall because of uncertainties, such as separation distance and the contact area. However, if the ratio is constant, which seems likely, the determination of the removal force may enable an indirect estimation of the adhesion force.

The adhesion of GI-103 cells to the quartz wall was reversible, and the adhesion site was located near the end of the cell. The surface properties, such as hydrophobicity or surface charge, near the end of the cell may be different from those of other parts of the cell, as suggested by Marshall \& Cruickshank (1973). These characteristics of adhesion may reflect a foregoing step of end-on irreversible adhesion of the cell as shown for marine bacteria (Marshall \& Cruickshank, 1973; Fletcher, 1979).

In natural environments the following situation seems to occur frequently: liquid flows parallel to substrate surfaces to which micro-organisms are attached, rather than there being a perpendicular force which works on micro-organisms. Thus, the method used in this study may be useful for the study of attached cells being removed by actual force. It seems difficult to wash away all microbial cells from a surface, providing the exponential distribution of the removal force among the attached cells as revealed in this study. This manner of cell attachment may play an important role in the survival of microbial populations, because some cells may tolerate even a large removal force and remain attached at the surface. They may then become irreversibly attached at the surface, resulting in the formation of biofilm, a microbial community, at the surface. This may explain the difficulties in preventing the biofouling of heat exchangers or ship surfaces in marine waters or the clogging of pipes.

It is expected that the experimental system used in the present study will serve to enhance the understanding of the interaction strength between microbes and surfaces, because this system can be applied to the study of many kinds of micro-organisms. If the surface properties of the quartz plate can be changed to mimic the surfaces found in natural environments, the present approach will be useful for the study of the adhesion mechanism and the behaviour of micro-organisms in diverse ecosystems.

The author wishes to express his appreciation to Y. Kasahara (Tohoku University) for kindly providing the GI-103 strain. The author is very grateful to Dr H. Kataoka (Tohoku University) and Prof. M. Tagawa (Nara Women's University) for their helpful discussion. Thanks are also due to the Ministry of Education, Science and Culture of Japan for the grant-in-aid to carry out this work.

\section{References}

Absolom, D. R., Lamberti, F. V., Policova, Z., ZingG, W., Van Oss, C. J. \& NeumanN, A. W. (1983). Surface thermodynamics of bacterial adhesion. Applied and Environmental Microbiology 46, 9097.

Bashan, Y. \& LeVanony, H. (1988). Adsorption of the rhizosphere bacterium Azospirillum brasilense Cd to soil, sand and peat particles. Journal of General Microbiology 134, 1811-1820.

Busscher, H. J., Weerkamp, A. H., Van Der Mei, H. C., Van Pelt, A. W. J., DE JoNG, H. P. \& ARENDS, J. (1984). Measurement of the surface free energy of bacterial cell surfaces and its relevance for adhesion. Applied and Environmental Microbiology 48, 980-983.

FLETCHER, M. (1979). The attachment of bacteria to surfaces in aquatic environments. In Adhesion of Microorganisms to Surfaces, pp. 85-108. Edited by D. C. Ellwood, J. Melling \& P. Rutter. London: Academic Press.

Goldman, A. J., Cox, R. G. \& Brenner, H. (1967). Slow viscous motion of a sphere parallel to a plane wall - II. Chemical Engineering Science 22, 653-660. 
Gotoh, K., Iriya, M., Mitsui, A. \& Tagawa, M. (1983). The detachment of nylon particles from quartz plate by electro-osmotic flow. Colloid and Polymer Science 261, 805-811.

Gotoh, K., Inoue, T. \& Tagawa, M. (1984). Adhesion of nylon particles to a quartz plate in an aqueous solution and their removal by electro-osmosis. Colloid and Polymer Science 262, 982-989.

Hermesse, M. P., Dereppe, C., Bartholome, Y. \& Rouxhet, P. G. (1988). Immobilization of Acetobacter aceti by adhesion. Canadian Journal of Microbiology 34, 638-644.

Kaneko, T. \& Colwell, R. R. (1975). Adsorption of Vibrio parahaemolyticus onto chitin and copepods. Applied Microbiology 29, 269-274.

Marshall, K. C. (1976). Interfaces in Microbial Ecology. Cambridge, MA: Harvard University Press.

Marshall, K. C. \& Cruickshank, R. H. (1973). Cell surface hydrophobicity and the orientation of certain bacteria at interfaces. Archiv für Mikrobiologie 91, 29-40.

Pratt-Terpstra, I. H., Weerkamp, A. H. \& Busscher, H. J. (1987).
Adhesion of oral streptococci from a flowing suspension to uncoated and albumin-coated surfaces. Journal of General Microbiology 133, 3199-3206.

RUTTER, P. R. \& VINCENT, B. (1980). The adhesion of micro-organisms to surfaces: physico-chemical aspects. In Microbial Adhesion to Surfaces, pp. 79-92. Edited by R. C. W. Berkeley, J. M. Lynch, J. Melling, P. R. Rutter \& B. Vincent. Chichester: Ellis Horwood.

TAdRos, TH. F. (1980). Particle-surface adhesion. In Microbial Adhesion to Surfaces, pp. 93-116. Edited by R. C. W. Berkeley, J. M. Lynch, J. Melling, P. R. Rutter \& B. Vincent. Chichester: Ellis Horwood.

TAGAWA, M. \& Gotoh, K. (1986). Removal of iron(III) oxide particles from a quartz plate by liquid flow. Colloid and Polymer Science 264, 1072-1079.

Van Loosdrecht, M. C. M., Lyklema, J., Norde, W., SchraA, G. \& ZEHNDER, A. J. B. (1987). The role of bacterial cell wall hydrophobicity in adhesion. Applied and Environmental Microbiology 53, 1893-1897. 